\title{
Where is queer theory in organizational studies?
}

\begin{abstract}
The main goal of this article is analyzing how queer theory is being applied in organizational studies. In other words, the goal understands how queer theory ideas and concepts are forged by organizational researchers, mainly searching to analyze the themes that are studied in organization using queer theory lenses as also the concepts approached and methodologies present in empirical research. To accomplish this aim a bibliographical research from 2008 to 2014 in EBSCO Business Source Premier, Emerald, Sage, Willey Online Library, Science Direct Freedom, Taylor \& Francis databases, and Ephemera: theory \& politics as carried out. Queer theory has been applied to different themes in organizational studies: friendship, humor and control, entrepreneurship, leadership and space. Despite queer theory being applied to many different themes most of these works still use queer theory to study aspects related to gender and sexuality. Research about race, class, ethnicity and the body is neglected in organizational studies and need to be developed by organizational researchers. Beyond that, there is a huge potential to apply queer theory's concepts to other aspects not related only to the study of minorities.
\end{abstract}

Keywords: queer theory, organizational studies, themes, concepts, bibliographical research
Volume I Issue 4 - 2017

\author{
Eloisio Moulin de Sousa \\ Department of Management, Federal University of Espirito \\ Santo, Brazil
}

Correspondence: Eloisio Moulin de Sousa, Department of Management, Federal University of Espirito Santo, Brazil, Email eloisiomoulin@gmail.com

Received: August 02, 2017 | Published: November 03, 2017

\section{Introduction}

Organizational studies is eminently a theoretical field. In this sense, the one of the main goals in organization studies is to search and develop new approaches to be applied and used in research that has relations with the process of organizing in contemporary society. Then, the main idea we can outline about this statement is that in this specific research organization does not mean an entity but a constant process of organizing our lives. ${ }^{1,2}$ In this sense, organizations are "better understood as the aggregative, unintended outcome of local efforts at ordering and regularizing our otherwise intractable and amorphous life word in order to make it more predictable and livable". In other words, "organization is more a tedious and interminable process of factioning out the real than a solid, static thing". ${ }^{3}$ One way in which to organize lives is related with gender and sexuality norms. Queer theory is a conceptual approach, among others, commonly used to understand the construction of social categories related with the normalization of gender and sexuality. Despite its intrinsic relation to gender and sexuality studies, there are strong indications that the use of queer theory has expanded beyond the study of gender and sexuality, particularly in other areas of study in the humanities and social sciences. For example, the international scientific congress Queering Paradigms (QP), which is not restricted only to organizational studies, was first held in England in 2008 with the purpose of discussing and questioning homophobic policies. In its latest edition, it starts to incorporate broader debates focused on discussion and questioning the process of standardization and marginalization in contemporary societies that goes beyond issues of gender and sexuality aiming to discuss identity concerns and their implications for theory, analysis, and methodology.

This can be demonstrated in the streams in the 2012 QP congress: Queering Bodies, Identities and Embodiment; Queering Epistemologies and Methodologies; Queering Institutions; Queering Language Practices; Queering Media Practices; Queering Races and Ethnicities and Queering Geographies and Temporalities. Therefore, the main objective of this article is to examine how queer theory is being used in organizational studies. In other words, the goal is understanding how queer theory ideas and concepts are forged by organizational researchers, mainly searching to analyze the themes that are studied in organization using queer theory lenses as also the concepts approached and methodologies present in empirical research. Thus, fulfilling its intention the article will first mean understanding key concepts contained in queer theory to afterward see how queer theory has been used in organizational studies.

\section{Queer theory's concepts}

Queer theory emerges in the 1980 s as a school of thought that questions the current forms of understanding social identities. Its inspiration comes from gay and lesbian studies, as well feminist theory, the American sociology of deviance and French post-structuralism. ${ }^{4}$ Queer theory precursors. ${ }^{4}$ However, the emergence of queer theory in the academic field is not precise. For example, Louro ${ }^{5}$ asserts that queer theory enters definitely into academic circles in 1986 with the publication of an article by the American historian Joan Scott entitled Gender: a useful category of historical analysis. In this article, Scott does not hide that she took concepts borrowed from Michel Foucault and Jacques Derrida to develop her ideas and concepts.

Other authors ${ }^{6,7}$ attributed the book Epistemology of the Closet written by ${ }^{7}$ as queer theory's founder text. About this subject, Halperin $^{8}$ also includes the book Gender Trouble written by Judith Butler as a foundational queer theory work. But, definitely, queer theory began years before the publishing of these works with the first edition of History of Sexuality published by Michel Foucault in $1976 .{ }^{9}$ According to Seidman ${ }^{10}$ queer theory is therefore a social constructionist approach that challenges essentialist or universalist understandings of gender and sexuality, questioning the operation of the binary logics related to gender and sexuality identities (for instance: hetero/homosexual; masculine/feminine), considering these identities as a social and political organizing principle. Intending to combat the universalizing and essentializing view of gender and sexuality queer theory affirms that identities are unstable categories 
and the universality and unity of identities categories are undermined by the restrictions of the discourse in which they function. ${ }^{11}$ Queer theory's main concern is related to the conception of human beings forged by Illuminists and/or Humanists. Then the queer theory is an attack on response to the universalism and essentialism present in Illuminist and/or Humanist approaches. Seidman ${ }^{12}$ also asserts that the main target of queer theory is the study of power relations within a Foucauldian perspective of analysis. Therefore, as Cohen ${ }^{13}$ avers, the central point to queer theory is not only to focus on the cultural construction of sexuality but to analyze the way which power is asymmetrically distributed among and within these sexual categories. In other words, queer theory concerns to problematize the normal. These ideas developed by queer theorists can be better understood approaching the following concepts: performativity and performance; heterosexual matrix and heteronormativity; subjectivity/identity and identification.

The social heteronormative logic is so present in so many social institutions in the world that queer has more of a target than to increase toleration or equal status in specific societies. Its main goal is challenging these institutions. Normative procreation patterns structures labeled as heterosexual regulate and produce the gender binary logic (male/female) producing intelligible genders. ${ }^{13}$ In this sense, intelligible genders are produced by regulatory practices that produce coherent identities and truths through coherent gender norms. ${ }^{11}$ Butler ${ }^{11}$ calls the regulatory practices of coherent gender norms the heterosexual matrix. She affirms that the internal unity and coherence of man or woman requires at the same time a stable and oppositional heterosexuality. Then, "institutional heterosexuality both requires and produces the univocity of each of the gendered terms that constitute the limit of gendered possibilities within an oppositional, binary gender system". ${ }^{11}$ Butler ${ }^{11}$ complements her affirmation showing that this kind of conception of gender "presupposes not only a causal relation among sex, gender and desire, but suggests as well that desire reflects or expresses gender and that gender reflects or expresses desire". ${ }^{11}$

The heterosexual matrix institutes the heterosexuality as being the pattern to be followed by individuals. As pattern, it operates as a norm that compels and regulates lives (heteronormativity). Heterosexual norms conduct us to think that to be successful in our lives we need to constitute heterosexual families and capital goods (for example: own house, car, among other capital goods). If we follow these heterosexual norms we are seen and considered as ethical people who obey the natural force of nature. ${ }^{14}$ If we do not follow heterosexual norms we are seen as a person who fails because of the nonconformity with reproductive lifestyles and capitalist practices, constituting what Butler ${ }^{15}$ called objects. As a set of regulatory practices, the heterosexual matrix through which identities related to gender and sexuality become intelligible means that some identities cannot exist, manly identities which break with and do not follow the determinist relation of sex-gender-sexuality. ${ }^{11}$ The heterosexual matrix is a political relation instituted by cultural laws that work as a regulator of the meaning of gender identity categories. However, the heterosexual matrix cannot be conceived as a fixed and deterministic structure. Gender norms work and are operated by the heterosexual matrix, soliciting in us the embodiment of some idealized characteristics of femininity and masculinity. Based on performativity affirms the power of the matrix and its norms. For example, Butler ${ }^{16}$ describes that when someone born and they are named as girl heterosexual norms initiate the symbolic power process that acts producing bodies, gestures, behaviors, clothes, desires to be mother and wife, and so on.
Then, the naming process produces someone as a viable subject according to the heterosexual matrix. Then, performativity affirms a binding power that works as a network of rewards and punishments which "include legal sentences, baptisms, inaugurations, declarations of ownership, statements that not only perform action, but confer a binding power on the action performed" ${ }^{16}$ In this sense, performativity occurs through discourse and it operates by discourse. Performativity is the uninterrupted and constant processes of repetitive heterosexual matrix norm citations. ${ }^{16}$

Therefore, performativity is not a singular and deliberate act it is power relations that operate by discourse. Performativity is not an intentional and conscientious act of a person and does not have its foundations in someone. On the contrary, its foundations are in binding power related to discourse. Queer theory in questioning the foundational categories of man and woman wishes to eliminate gender or proliferate it beyond the male-female dichotomy. ${ }^{17}$ Thus, queer theory tends to see gender as something fluid, negotiated, created through repeated performances, not something fixed and innate. Performativity "is neither free play nor theatrical self-representation; nor can it be simply equated with performance". ${ }^{15}$

Performativity needs to be thought of as the process that regulates the repetition of norms. Then, repetition is not performed by a subject; on the contrary, repetition is what allows, enables and produces the subject. It means that performativity is not a singular act performed by a subject, but the temporal condition for the subject; performativity is the process which the subject is constituted as subject. Behaviors seem to be real, normal, and natural because the subject is performatively induced to do performances according to norms and social conventions. ${ }^{18}$

Then, performativity constitutes the possible performances that can be enacted in a specific context. Therefore, performance and performativity are not the same things, and performativity needs to be understood not as a self-expression/presentation, "but as the unanticipated resignifiability of highly invested terms". ${ }^{16}$ The subject is not free and outside of norms, but is produced through the constant repetition of these norms.

Due to this Butler ${ }^{16}$ believes that the "critique of the queer subject will be central to queer politics to the extent that it constitutes a selfcritical dimension within activism". This critique of the subject works as "a persistent reminder to take the time to consider the exclusionary force of one of activism's most treasured contemporary premises". ${ }^{16}$ In queer theory the subject "is understood to be constructed and contained by multiple practices of categorizations and regulation". ${ }^{13}$ For queer theory identities are always fluid, heterogeneous, political, and even paradoxical. ${ }^{18}$ The queer theory argues that "identities are always multiple or at best composites with literally an infinite number of ways in which 'identity-components' (e.g., sexual orientation, race, class, nationality, gender, age, able-ness) can intersect or combine". ${ }^{10}$ However, besides queer theory considering identity disperse gender and sexual identities cannot be seen only as identities, but they need to be seen as categories of knowledge framed by discourse.

Identity and subjectivity in queer theory need to be understood as meaning identification or recognition. People e are bound to an identity in a process of identification. It means that individuals are induced by power relations to identify themselves in the symbolic order searching for a compulsory recognition to become subjects. ${ }^{19,16}$ However, "identification with elements in the symbolic order is never complete". ${ }^{19}$ For the subject the symbolic order seems to have 
oneness and certainties, but it is really replete with discrepancies and instabilities. As a consequence it produces a self always "split, incomplete and struggling". ${ }^{19}$ Due to the incompleteness of the self, the subject fails to accomplish complete recognition compelling them to always be searching for and desiring recognition and at the same time affirming the impossibility of accomplishment of the subject. Nonetheless, the subject does not have an option to existing outside of the symbolic order and despite its failure to accomplish recognition, it is better to exist in subordination to this order rather than not existing as a subject. ${ }^{19}$ Then, once explained the main features and concepts of queer theory, the next topic will approach the methodology developed.

\section{Methodology}

This research is not a purely bibliometric study. In this sense Spinak $^{20}$ defines bibliometrics in different ways and for the author bibliometrics can be seen as

a) A multidisciplinary discipline;

b) The study of scientific publications to identify authors;

c) Trends and relationships between authors;

d) A quantitative study of published literature;

e) The quantitative study of the production of documents, among other forms.

Thus, one of the main characteristics of bibliometrics is to use statistical methods to analyze the scientific production of a particular area or database. Despite this research looking for trends in organization studies related to the queer theory, it is not characterized only as a bibliometric review. The research intentions are not only to demonstrate statistical information about the knowledge produced related to the queer theory in the organizational field. Beyond some statistical information about queer theory in organizational studies the research also seeks to understand how queer theory is used in the organizational field, characterizing this research as a bibliographic research too, trying to establish an overview of queer theory in organization studies. According to Gill, ${ }^{21}$ bibliographical research goes beyond bibliometric research because it also involves reading, analyzing and interpretation of journals and books. Therefore, you must perform a systematic and careful reading of the material that was collected through a previous screening to use it as the theoretical foundation of empirical research or as a basis for new formulations of a given theory.

After that, to accomplish the research goals a bibliographical research was done on article production related to queer theory in organization studies over the past five years (from 2008 to 2014) available in the following databases: EBSCO Business Source Premier, Emerald, Sage, Willey Online Library, Science Direct Freedom, Taylor \& Francis. The journal Ephemera: theory \& politics in organization was also searched, but separately because it does not belong to any databases. To select the articles from their respective databases and journals the following keywords were used: queer, queering, post-structuralism, gender, sexuality (or sexualities), postmodernism and cultural studies. The words queer, queering, poststructuralism, gender, sexuality (or sexualities), postmodernism and cultural studies were searched for in any part of the articles and not only in their title, abstract or keywords. Some samples of management and business journals that belong to the databases analyzed are presented below (Table 1).

Table I Data Bases and their Journals

\section{Data base Journals}

EBSCO Business Economica; Equality, Diversity and Inclusion (belonged to Emerald too until 20I I); Gender Work and Organization (until 20I I); Harvard

Source Premier Business Review; Industrial \& Labor Relations Review; Journal of Employment Counseling; Journal of Management Studies; Journal of

Workplace Rights; Public Administration; The Career Development Quarterly

Accounting, Auditing \& Accountability Journal;American Journal of Business; Applications of Management Science; Empowerment in Organization; Equal Opportunities International; Equality, Diversity and Inclusion (until 20I I); European Journal of Marketing; Gender in Management:An International Journal; International Journal of Organizational Analyses; International Journal of Retail \& Distribution Management; Journal of Consumer Marketing; Journal of Fashion Marketing and Management; Journal of Historical

Emerald Research in Marketing; Journal of Islamic Marketing; Journal of Management History; Journal of Management Development; Journal of Organizational Change Management; Journal of Organizational Ethnography; Leadership \& Organization Development Journal; Management Development Review; Management Research Review; Management Research:The Journal of the Iberoamerican Academy of Management; Policing:An International Journal of Police Strategies \& Management; Qualitative Market Research:An International Journal; Qualitative Research in Organizations and Management; Society and Business Review; Women in Management Review

Action Research;Administration \&Society;Administrative Science Quarterly (belongs to EBSCO too);Advances in Developing Human Resources; The American Review of Public Administration;Australian Journal of Management; Educational Management Administration \& Leadership; Group \& Organization Management; Human Relations; Human Resource Development Review; International Journal of Cross Cultural Management; International Review of Administrative Sciences; International Small Business Journal; Journal of Human Sage $\quad$ Values; Journal of Industrial Relations; Journal of Management Inquiry; Journal of Travel Research; Journal of Vacation Marketing; Labor Studies Journal; Leadership; Management and Labour Studies; Management \& Organizational History; Management Communication Quarterly; Management Learning; Marketing Theory; Nonprofit and Voluntary Sector Quarterly; Organization; Organization Studies; Organizational Research Methods; Public Relations Inquiry; Review of Market Integration; Simulation \& Gaming; Small Group Research; Tourism and Hospitality Research;Transactional Analysis Journal;Work, employment and society

\footnotetext{
Willey Online Academic Review;Account Perspectives; British Journal of Management; Business Ethics:A European Review; Business and Society Library Review; The Career Development Quarterly; Gender,Work and Organization (belonged to EBSCO too until 201 I); International Labour Review; Journal of Management Studies; Management and Organization Review
} 
Table Continued....

\begin{tabular}{|c|c|c|c|}
\hline Data base & \multicolumn{3}{|l|}{ Journals } \\
\hline $\begin{array}{l}\text { Science Direct } \\
\text { Freedom }\end{array}$ & \multicolumn{3}{|c|}{$\begin{array}{l}\text { Accounting Forum; Accounting, Management and Information Technologies; Accounting, Organizations and Society; European Journal } \\
\text { of Purchasing \& Supply Management; European Management Journal; Global Economics and Management Review; Human Resource } \\
\text { Management Review; Industrial Marketing Management; Information \& Management; Information Processing \& Management; Journal of } \\
\text { Hospitality and Tourism Management; Journal of International Management; Scandinavian Journal of Management; Tourism Management; } \\
\text { Tourism Management Perspectives }\end{array}$} \\
\hline Taylor \& Francis & \multicolumn{3}{|c|}{$\begin{array}{l}\text { The Academy of Management Annals; Accounting and Business Research;Accounting in Europe; Action Learning: Research and Practice; } \\
\text { Applied Economics; Asia Pacific Journal of Public Administration; Construction Management and Economics; Consumption Markets } \\
\text { \& Culture; Culture and Organization; Enterprise and Innovation Management Studies; Entrepreneurship \& Regional Development:An } \\
\text { International Journal; Human Resource Development International }\end{array}$} \\
\hline \multirow{5}{*}{\multicolumn{2}{|c|}{$\begin{array}{l}\text { One hundred and fifty four (154) articles using these criteria in } \\
\text { the databases analyzed and ephemera from the period January } 2008 \\
\text { to March } 2014 \text { distributed in this way: } 9 \text { (nine) articles in EBSCO } \\
\text { Business Source Premier; } 37 \text { (thirty seven) in Emerald; } 16 \text { (sixteen) in } \\
\text { Willey Online Library; } 84 \text { (eighty four) in SAGE; } 3 \text { (three) in Science } \\
\text { Direct Freedom; } 1 \text { (one) in Taylor \& Francis and } 4 \text { (four) in Ephemera } \\
\text { Journal. However, } 2 \text { (two) articles found in EBSCO and Willey Online } \\
\text { Library databases were the same Gender, Work and Organization } \\
\text { belonged to both databases until 2011. After this analysis the real } \\
\text { amount of different articles found related to queer theory is } 152 \text { (one } \\
\text { hundred and fifty two). After this, all } 152 \text { (one hundred and fifty two) } \\
\text { articles were read to see if they have connections and relations with } \\
\text { queer theory (Table 2). }\end{array}$}} & \multicolumn{2}{|c|}{$\begin{array}{l}\text { articles that do not have any possibility of connections and relations } \\
\text { to queer theory and from the } 152 \text { (one hundred and fifty two) articles } \\
\text { analyzed only } 59 \text { (fifty nine) have some possibility of connections and } \\
\text { relations to queer theory. The distribution of these articles can be seen } \\
\text { below (Table 3). } \\
\text { Table } 2 \text { Amount Articles Found }\end{array}$} \\
\hline & & Data bases & Amount articles found \\
\hline & & EBSCO Business Source Premier & 9 \\
\hline & & Emerald & 37 \\
\hline & & Willey Online Library & 16 \\
\hline \multirow{4}{*}{\multicolumn{2}{|c|}{$\begin{array}{l}\text { In this primary stage, for a paper to be considered as having some } \\
\text { relation to queer theory the following aspects were analyzed: the } \\
\text { goal of the article, the concepts used and elaborated by the authors, } \\
\text { the theoretical framework of the article and in the case of empirical } \\
\text { papers the methodology used. This first analysis intended to eliminate }\end{array}$}} & SAGE & 84 \\
\hline & & Science Direct Freedom & 3 \\
\hline & & Taylor \& Francis & I \\
\hline & & Ephemera Journal & 4 \\
\hline
\end{tabular}

Table 3 First Analysis Queer Articles

\begin{tabular}{|c|c|c|}
\hline Data base & Total articles & Journals \\
\hline $\begin{array}{l}\text { EBSCO } \\
\text { Business Source } \\
\text { Premier }\end{array}$ & 4 & Gender,Work and Organization ( 3 articles); Public Administration (I article) \\
\hline Emerald & 13 & $\begin{array}{l}\text { Career Development International (I article); Equality, Diversity and Inclusion:An International } \\
\text { Journal ( } 6 \text { articles); Gender in Management:An International Journal ( } 3 \text { articles); Journal of } \\
\text { Organizational Change Management (I article); Qualitative Market Research:An International } \\
\text { Journal (I article) and Society and Business Review (I article) }\end{array}$ \\
\hline $\begin{array}{l}\text { Willey Online } \\
\text { Library }\end{array}$ & 10 & Gender,Work and Organization ( 10 articles). \\
\hline SAGE & 29 & $\begin{array}{l}\text { Advances in Developing Human Resources ( } 3 \text { articles); Group \& Organization Management; Human } \\
\text { Relations ( } 8 \text { articles); International Journal of Cross Cultural Management (I article); International } \\
\text { Small Business Journal (I article); Journal of Management Inquiry (I article); Journal of Vacation } \\
\text { Marketing (I article); Leadership (I article); Management Learning (I article); Marketing Theory (I } \\
\text { article); Organization ( } 9 \text { articles); Organization Studies ( } 2 \text { articles) }\end{array}$ \\
\hline $\begin{array}{l}\text { Science Direct } \\
\text { Freedom }\end{array}$ & 2 & Scandinavian Journal of Management ( 2 articles) \\
\hline Taylor \& Francis & $\mathrm{I}$ & Culture and Organization ( $\mathrm{I}$ article) \\
\hline
\end{tabular}

No article that could be related to queer theory in the journal of articles found that have some relations to queer theory is 58 (fifty Ephemera: theory \& politics in organization. Another important consideration is that 1 (one) article that has connections to queer theory was found in Gender, Work and Organization appeared in two databases analyzed: EBSCO and Willey Online Library for reasons sorted above. Then, considering this aspect the correct total amount eight). However, in the first reading was not so clear that all of the 58 articles selected belong to queer theory. But, in case of doubt if an article belongs or not to queer theory it was decided to classify it as being queer in this first reading to reread it again. Due that, all 58 articles were read again searching to understand if they really use 
queer concepts developed by queer theorists. Many articles analyzed use post-structuralism, post-colonialism and cultural approaches. But, despite that they cannot be considered as queer articles due they do not work with concepts and ideas considered queer. Therefore, after the second read 33 (thirty three) articles remained as belonging to queer theory as follow below: (Table 4).

Table 4 Second Analysis Queer Articles

\begin{tabular}{|c|c|c|}
\hline Data base & Total & Journals after second reading \\
\hline $\begin{array}{l}\text { EBSCO } \\
\text { Business } \\
\text { Source } \\
\text { Premier }\end{array}$ & 3 & $\begin{array}{l}\text { Gender, Work and Organization ( } 2 \\
\text { articles); Public Administration (I } \\
\text { article) }\end{array}$ \\
\hline Emerald & 6 & $\begin{array}{l}\text { Career Development International } \\
\text { (I article); Equality, Diversity and } \\
\text { Inclusion:An International Journal } \\
\text { ( } 2 \text { articles); Gender in Management: } \\
\text { An International Journal ( } 2 \text { articles); } \\
\text { Qualitative Market Research:An } \\
\text { International Journal (I article) }\end{array}$ \\
\hline Willey & 8 & $\begin{array}{l}\text { Gender, Work and Organization (10 } \\
\text { articles). }\end{array}$ \\
\hline SAGE & 15 & $\begin{array}{l}\text { Advances in Developing Human } \\
\text { Resources (I article); Human } \\
\text { Relations (6 articles); International } \\
\text { Small Business Journal (I article); } \\
\text { Journal of Vacation Marketing (I } \\
\text { article); Leadership (I article); } \\
\text { Management Learning (I article); } \\
\text { Organization ( } 2 \text { articles); } \\
\text { Organization Studies (2 articles) }\end{array}$ \\
\hline
\end{tabular}

Taylor \&
Francis

After that, the 33 (thirty three) articles were read again carefully and deeply to analyze how they use queer theory and their possible contribution to the Organizational field. Just after achieved these studies was possible to analyze where queer theory is used in organization studies, that means to understand the main queer theory concepts used and the objects/themes approached in organizational studies. The next topic analyses the queer articles found seeking to understand what themes and concepts are developed by organizational researchers. To accomplish this task these 33 articles were reread again carefully searching to understand what queer concepts were used in each article and how these concepts were defined by the authors, the main theme and goal of the article, with the articles, use queer concepts to analyze new themes beyond gender and sexuality and the methodology applied in case of empirical research. All of these article aspects were tabulated for later the data found in the articles to be compared and analyzed.

\section{Queer in the organizational field}

Many of the 152 articles found in the first search were eliminated mainly due to two reasons:

i. They do not use queer theory concepts and ideas in their theoretical approaches, ii. The articles were selected by the system because they have the words queer or queering in their text, but the use of these terms does not related to queer theory.

About the use of the term queer, it is relevant to explain that the articles eliminated utilize this term in two different ways none has any relation with queer theory as follows: queer is used as meaning a population represented by all marginalized sexualities present in the acronym LGBT (Lesbian, Gay, Bisexual and Transgender); and queer is used as just meaning male homosexuals. Related to the word queering the term was used in some papers as meaning two aspects: the process to bring LGBT issues to management disciplines independently of the conceptual approach used; and queering (Q) to another different sort of specific sexual identity supplementing the acronym LGBT to become LGBTQ. The forthcoming topics will discuss how queer theory has been used in the organizational field by the analysis of the 33 (thirty three) articles found. Therefore, to better understand the uses of queer theory in management studies the next topic identifies the concepts used by these articles, the themes worked through in the papers, the objects of analysis and the type of methodology used in empirical research to try to understand how the organizational field has appropriated queer theory.

\section{Analysis of queer theory's uses in management}

This section intends to analyze how queer theory has been appropriated by the organizational field. To accomplish this goal the queer concepts used will be analyzed, themes and objects worked through in the articles and the methodology used in empirical research. Before starting these analyses it is valuable to explain that some of the 33 articles employ the term queering in their text meaning a verb and not another kind of sexual identity nor a process to bring LGBT issues into the management discipline. In this sense the term queering is employed as meaning the reflexive action to problematize what is considered socially, culturally or biologically natural, universal, essential, reified, solid, stable and unproblematic. Therefore, the expression queering in queer articles does not mean a different sort of sexual identity or a curricular content, but the reflexive academic action that seeks to disrupt the established social order.

Queer ideas and concepts appear for the first time in organizational studies with the article 'Unpacking Priscilla: Subjectivity and Identity in the Organization of Gendered Appearance' by. ${ }^{22}$ But, despite without a shadow of doubt being an original queer text in which queer concepts are deeply discussed and developed, Brewis' et al. ${ }^{22}$ do not use the expression queer theory in their text. The first author to bring this label to the management discipline was Parker ${ }^{23}$ with the article Fucking Management: Queer, Theory and Reflexivity. Henceforth, queer theory begins to be used more widely in organizational studies, mainly in studies about aspects of gender and sexuality in the workplace as will be shown late.

About the queer concepts utilized by the authors, it is important to explain that some articles analyzed use more than one queer concept in their theoretical framework. Due to this, some papers appear more than once in (Table 5). The main concepts used by the authors of their papers can be organized into six categories: performativity and performance; the heterosexual matrix and heteronormativity; subjectivity, identity and identification; debating concepts related to gender; embodiment; and knowledge. However, as (Table 5) shows, it can be affirmed that only three main conceptual categories are largely worked through and used in organizational studies: 

i. Performativity and performance (twelve articles);
ii. Heterosexual matrix and heteronormativity (fifteen articles), and
iii. Subjectivity, identity and identification (twelve articles).

Table 5 Queer Concepts and Ideas Used in Organization Studies Articles

\begin{tabular}{ll}
\hline Queer concepts used & Articles' authors \\
\hline Performativity and Performance & $26,29,32,34,36,38,43,44,47,51,53$ \\
Heterosexual Matrix and Heteronormativity & $25,28,30-34,44,45,47,49,51,52,55,56$ \\
Subjectivity, Identity Categories and Identification & $26,35,36,37,40,41,46,47,50,55,54,56$ \\
Debating Concepts about Gender & 42,48 \\
Embodiment & 39 \\
Knowledge & 27 \\
\hline
\end{tabular}

Therefore, most of the articles are focused and centered on applying Butler's concepts in the organizational field, as Butler ${ }^{11,15,16,24}$ is the main author utilized by organizational researchers in this regard. Butler's concepts related to performativity, heteronormativity and identity construction are the main approaches and directions of construction of the ideas and analysis presented by the articles' authors. Important queer concepts developed by other queer theorists like $\mathrm{e}^{1-5}$ are not regularly used in organizational studies (Table 5).

There is a huge diversity of themes studied in the organizational field that use queer theory concepts. Finding this diversity is very interesting because it shows the connections established between queer theory and management. In other words, the connections highlight which organizational phenomena are analyzed using queer theory. Table 6 points to ten different themes that are connected with queer theory in this regard: appropriation of queer theory by different management disciplines and approaches; studies of friendship at work; identity/subjectivity construction; studies of beauty; diversity programs and policies; humor and comedy in the workplace; spatial division; entrepreneurship; leadership; and discrimination at work (Table 6).

Table 6 Themes and Objects Analyzed in Organizational Studies Articles

\begin{tabular}{lll}
\hline Themes & Aspect analysed (object of analysis) & Articles' authors \\
\hline $\begin{array}{l}\text { Appropriation of Queer Theory by Management } \\
\text { Disciplines and Theoretical Approaches }\end{array}$ & Bringing Sexuality (LGBT) issues to Human Relations Discipline & 27 \\
& Problematizing the discipline of public administration & 28 \\
& Problematizing Critical Management Studies as a Performative Approach & 29 \\
Friendship & Sexuality and Gender & $30-33$ \\
Subjectivity/ldentity & Gender and Sexuality & $19,25,3,7,41,42,46,51,52,56$ \\
& Expatriates & 36 \\
& Intersection among Race, Gender and Class & 50 \\
Beauty & Problematizing Binarity in gender, race and sexual identity & 54 \\
Organizational Diversity Policies and Programs & Gender and the Body & 38 \\
Humour and Comedy & Sexuality and Gender & $39,40,47,48,55$ \\
& Control and Subversion & 19 \\
Space & Gender & 44 \\
Entrepreneurship & Gender & 43 \\
Leadership & Gender and Sexuality & 35 \\
Discrimination at Work & Charisma & 45,49 \\
\hline
\end{tabular}

However, when our attention is directed to the main object and aspect analyzed under these themes their diversity collapses. From the thirty three articles found twenty seven relations to and have as their main object of analysis aspects of gender and sexuality. Therefore, despite the diversity of themes presented by the articles queer theory continues to be utilized mostly to study aspects of gender and sexuality inside these themes. Only six articles do not have any kind of relation to sexuality and gender studied, having as their main objects of analysis charisma, ${ }^{25}$ control and subversion, ${ }^{26}$ identity of expatriates and the knowledge produced in management studies. ${ }^{27-29}$ But despite most articles analyzed have relation to gender and sexuality the themes explored in these articles are diversified as highlighted.
Analyzing the themes studied by the organizational authors can be verified in the last decade a significant increase of empirical research that uses queer ideas in the management field. Queer concepts have been used to study a large range of themes in management: friendship in the workplace, ${ }^{30-33}$ leadership, ${ }^{34,25}$ subjectivity and identity ${ }^{35-37}$ beauty and body, ${ }^{38}$ sexual orientation and sex agenda, ${ }^{39,40}$ gender and performativity, ${ }^{41,42}$ humour, ${ }^{26}$ and relations between space and gender. ${ }^{43}$ From the thirty three works found twenty four reports empirical research.

As Table 7 shows the empirical studies accomplished use eight different sorts of methods and sometimes more than one kind of 
method was used in the same piece of empirical research. The most usual method is the interview as follows: semi-structured/structured interviews (13 articles); ethnography including auto-ethnography (4 articles); netnography (1 article); document analysis (4 articles); participant observation (1 article); multi-modal approach (1 article); focus group ( 1 article), and even quantitative survey ( 1 article). The papers that simultaneously used two different kinds of methodologies $\operatorname{are}^{43,44}$ (Interview and Focus Group) and ${ }^{25}$ (Interview and Quantitative Survey) (Table 7). Although the main object of analysis of the queer articles analyzed is some relation to gender and sexuality, some of these articles bring new insights about queer concepts. They develop new ideas related to these objects mainly about identity construction and organizational knowledge. ${ }^{45-50}$

Table 7 Methods Used In Queer Empirical Research in Organizational Studies

\begin{tabular}{ll}
\hline Methodology & Articles' authors \\
\hline Interview & $25,30-34,36,40,41,43,49,52,56$ \\
Ethnography and Auto-ethnography & $19,35,37,42$ \\
Netnography & 38 \\
Document Analysis & $39,44,53,51$ \\
Participant Observation & 43 \\
Multi-modal Approach & 46 \\
Focus Groups & 43 \\
Quantitative Survey & 25
\end{tabular}

\section{Conclusion}

As demonstrated queer theory has been already applied to different themes in organizational studies: friendship, humor and control, entrepreneurship, leadership and space. However, despite being applied to different themes many of these works still use queer theory to study aspects of gender and sexuality in friendship, entrepreneurship, leadership and space. ${ }^{51-53}$ Research about race, class, ethnicity and the body is marginal in studies that use queer theory concepts and need to be more developed by organizational researchers. Beyond that, the use of queer theory in management studies about gender and sexuality is restricted only to studying identities related to minorities and it is necessary to expand its use to race, gender and sexual identities considered hegemonic like men, white, heterosexual, for instance. Therefore, queer theory is not an umbrella for studying minorities and it studies all kind of processes of normalization which produce both the normal and abnormal. Just proceeding that way the binary logic where difference means only a question of us-them can be broken.

Hence, the queer theory should not be defined as a study of gay men, lesbians, transsexuals, bisexuals, women, black people, and so on. Firstly, studying these minority identities does not make a piece of research queer. In other words, it is not having as a subject of study gay men that makes research queer. ${ }^{54}$ Then, what allows research to be considered queer is not only studying gay men or lesbians, but the way which identities are understood and worked through in the research independently whether the subjects studied are gays or not.

The analysis accomplished in the articles allows expanding queer concepts to other organizational aspects not related to gender, race, ethnicity, and sexuality only. ${ }^{55,56}$ Hence, in addition to the analysis of the production of difference among human beings that operates classifying them under a normal/abnormal and minority/hegemonic binary logic two main objects/themes of study were identified to which queer theory can be applied these are not related to the productions of differences related to sexuality and gender:

i. Identity construction in the workplace;

ii. Epistemological issues about management disciplines and

iii. Ontological aspects about the concept of organization.

\section{Acknowledgments}

This research was sponsored by Conselho Nacional de Desenvolvimento Científico e Tecnológico (CNPq).

\section{Conflict of interest}

The author declares no conflict of interest.

\section{References}

1. Cooper R. Organization/Disorganization. Social Science Information. 1986;25(2):299-335

2. Munro R. Unmanaging/Disorganisation. Ephemera: critical dialogues on organization. 2001;1(4):395-403.

3. Chia R. Ontology: organization as world-making. In: Westwood R, Clegg $\mathrm{S}$, editors. Debating organization: point-counterpoint in organizations studies. UK: Blackwell Publishing Ltd, Oxford; 2003. p. 98-113.

4. Pino NP. Queer Theory and the Intersex: Invisible Experiences of UnDone Bodies. Cadernos Pagu. 2007;28:149-174.

5. Louro GL. Gênero, sexualidade e educação:uma perspectiva pósestruturalista. Brazil: Vozes; 2008. 184 p.

6. Gamson J. Sexualities, Queer Theory, and qualitative research. In: Denzin N, Lincoln YS, editors. The landscape of qualitative research: theories and issues. USA: Sage Publications; 2003. p. 540-568.

7. Sullivan N. A critical introduction to queer theory. New York: New York University Press; 2003.

8. Halperin DM. The normalization of Queer Theory. Journal of Homosexuality. 2003;45(2-4):339-343.

9. Warner M. Queer and then? The end of queer theory? The Chronicle of Higher Education. 2012;58(18):1-5.

10. Seidman S. Queer theory/sociology. UK: Blackwell Publishers; 1996. $11 \mathrm{p}$.

11. Butler J. Gender trouble: feminism and the subversion of identity. UK: Routledge Classics; 1990. 92 p.

12. Seidman S. Theoretical perspectives. In: Seidman S, et al. editors Handbook of the new sexuality studies. USA: Routledge; 2006.

13. Cohen CJ. Punks, bulldaggers, and welfare queens: the radical potential of queer politics? GLQ. 1997;3:437-465.

14. Halberstam J. Oh Behave! Austin Powers and the Drag Kings. GLQ 2001;7(3):425-452.

15. Butler J. Bodies that matter: on the discursive limits of "sex". USA: Routledge; 1993. 64 p.

16. Butler J. Critically Queer. GLQ. 1993;1:17-32.

17. Gardner JK. Men, masculinities and feminist theory. In: Kimmel MS, et al. editors. Handbook of studies on men \& masculinities. USA: Sage Publications; 2005. 16 p.

18. Lovaas KE, Jenkins MM. Introduction: setting the stage. In: Lovaas KE, Jenkins MM, editors. Sexualities and communication in everyday life: $a$ reader. USA: Sage Publications; 2007. p. 1-18. 
19. Kenny K. 'Someone Big and Important': Identification and Affect in an International Development Organization. Organization Studies. 2012;33(9):1175-1193.

20. Spinak E. Indicadores cienciométricos. Ciência da Informação. 1998;27(2):141-148.

21. Gill AC. Como elaborar projetos de pesquisa. 4th ed. Brazil: Atlas; 2002. $176 \mathrm{p}$.

22. Brewis J, Hampton MP, Linstead S. Unpacking Priscilla: Subjectivity and Identity in the Organization of Gendered Appearance. Human Relations. 1997;50(10):1275-1304.

23. Parker M. Fucking Management: Queer, Theory and Reflexivity. Ephemera: critical dialogues on organization. 2001;1(1):36-53.

24. Butler J. Undoing gender. UK: Routledge, Oxford shire; 2004. 20 p.

25. Harding $\mathrm{N}$, Lee $\mathrm{H}$, Ford $\mathrm{J}$, et al. Leadership and charisma: A desire that cannot speak its name? Human Relations. 2011;64(7):927-949.

26. Kenny K, Euchler G. 'Some Good Clean Fun': Humour, Control and Subversion in an Advertising Agency. Gender, Work and Organization. 2012;19(3):306-323.

27. Gedro J. Understanding, deigning, and teaching LGBT issues. Advances in Developing Human Resources. 2010;12(3):352-366.

28. Lee H, Learmonth M, Harding N. Quee(y)ing Public Administration. Public Administration. 2008;86(1):149-167.

29. Spicer A, Alvesson M, Kärreman D. Critical performativity: the unfinished business of critical management studies. Human Relations. 2009;62(4):537-560.

30. Rumens N. The complexities of friendship: exploring how gay men make sense of their workplace friendship with straight women. Culture and Organizations. 2008;14(1):79-95.

31. Rumens N. Working at intimacy: Gay men's workplace friendships. Gender, Work and Organization. 2008;15(1):9-30.

32. Rumens N. Workplace friendships between men: gay men's perspectives and experiences. Human Relations. 2010;63(10):1541-1562.

33. Rumens N. Queering cross-sex friendships: an analysis of gay and bisexual men's workplace friendships with heterosexual women. Human Relations. 2012;65(8):955-978.

34. Muhr SL, Sullivan KR. "None so queer as folk": Gendered expectations and transgressive bodies in leadership. Leadership. 2013;9(3):416-435.

35. Calás M, Ou H, Smircich L. "Woman" on the move: mobile subjectivities after intersectionality. Equality, Diversity and Inclusion: An International Journal. 2013;32(8):708-731.

36. Scurry T, Rodriguez JK, Bailouni S. Narratives of identity of selfinitiated expatriates in Qatar. Career Development International. 2013;18(1):12-33.

37. Mcdonald J. Coming out in the field: a queer reflexive account of shifting researcher identity. Management Learning. 2013;44(2):127-143.

38. Gurrieri L, Cherrier H. Queering beauty: fatshionistas in the fatosphere. Qualitative Market Research: An International Journal. 2013;16(3):276295.
39. Thanem T. Free At Last? Assembling, Producing and Organizing Sexual Spaces in Swedish Sex Education. Gender, Work and Organization. 2010;17(1):91-112.

40. Beckett C. Silence in the sexual agenda of a UK probation service. Equality, Diversity and Inclusion: An International Journal. 2012;31(8):753-767

41. Billing YD. Are Women in Management Victims of the Phantom of the Male Norm? Gender, Work and Organization. 2011;18(3):298-317.

42. Baines D. Gender Mainstreaming in a Development Project: Intersectionality in a Post-Colonial Un-doing? Gender, Work and Organization. 2010;17(2):119-149.

43. Tyler M, Cohen L. Spaces that Matter: Gender Performativity and Organizational Space. Organization Studies. 2010;31(2):175-198.

44. Tyler M, Cohen L. Management in/as comic relief: Queer Theory and gender performativity in The Office. Gender, Work and Organization. 2008;15(2):113-132.

45. Helene Ahl, Susan Marlow. Exploring the dynamics of gender, feminism and entrepreneurship: advancing debate to escape a dead end? Organization. 2012;19(5):543-562.

46. Ainsworth S, Cutcher L. Expectant Mothers and Absent Fathers: Paid Maternity Leave in Australia. Gender, Work and Organization. 2008;15(4):375-393.

47. Bendl R, Fleischmann A. Diversity management discourse meets queer theory. Gender in Management: An International Journal. 2008;23(6):382-394.

48. Bendl R, Schimidt A. Gender Mainstreaming: An Assessment of Its Conceptual Value for Gender Equality. Gender, Work and Organization. 2013;20(4):364-381.

49. Galloway L. The experiences of male gay business owners in the UK. International Small Business Journal. 2011;30(8):890-906.

50. Holvino E. Intersections: The Simultaneity of Race, Gender and Class in Organization Studies. Gender, Work and Organization. 2010;17(3):248277.

51. Knights D, Tullberg M. Managing masculinity/mismanaging the corporation. Organization. 2011;19(4):385-404.

52. Ozturk MB. Sexual orientation discrimination: Exploring the experiences of lesbian, gay and bisexual employees in Turkey. Human Relations. 2011;64(8):1099-1118.

53. Phillips M, Knowles D. Performance and Performativity: Undoing Fictions of Women Business Owners. Gender, Work and Organization. 2012;19(4):416-437.

54. Prasad A. Beyond analytical dichotomies. Human Relations. 2012;65(5):567-595.

55. Swan E. "A testing time, full of potential?" Gender in management, histories and futures. Gender in Management. 2010;25(8):661-675.

56. Therkelsen A, Blichfeldt BS, Chor J, et al. 'I am very straight in my gay life': Approaching an understanding of lesbian tourists' identity construction. Journal of Vacation Marketing. 2013;19(4):317-327. 